\title{
Effects of Hypoxia, Hypoglycemia, and Muscle Shortening on Cell Death in the Sheep Ductus Arteriosus
}

\author{
SETH GOLDBARG, TIMOTHY QUINN, NAHID WALEH, CHRISTINE ROMAN, BAO MEI LIU, \\ FRANÇOISE MAURAY, AND RONALD I. CLYMAN \\ Cardiovascular Research Institute [S.G., T.Q., N.W., C.R., B.M.L., F.M., R.I.C.], Department of Pediatrics \\ [T.Q., R.I.C.], University of California, San Francisco, San Francisco, California 94143-0544, U.S.A.; \\ Pharmaceutical Discovery Division, SRI International, Menlo Park, California 94025, U.S.A. [N.W.]
}

ABSTRACT

\begin{abstract}
After birth, constriction of the full-term ductus arteriosus produces ischemic hypoxia, caspase activation, DNA fragmentation $(>70 \%$ of cell nuclei are positive by the terminal deoxynucleotidyl transferase nick-end labeling [TUNEL] technique), and permanent ductus closure. In contrast, the preterm ductus frequently fails to develop these changes. We used the TUNEL technique to examine rings of fetal ductus arteriosus (incubated for $24 \mathrm{~h}$ at different oxygen and glucose concentrations) to determine the roles of 1) constriction and shortening, 2) hypoxia, and 3) hypoglycemia in producing cell death. Under controlled conditions, late-gestation ductus rings had a low rate of TUNELpositive staining $(0.6 \pm 0.9 \%)$ that did not change during muscle shortening. Although hypoxia $(6.9 \pm 3.5 \%)$ and hypoglycemia $(2.4 \pm 1.9 \%)$ increased the incidence of TUNEL-positive staining, only the combination of hypoxia-plus-hypoglycemia increased the incidence to the range found in vivo $(83 \pm 9.5 \%)$. The combination of hypoxia-plus-hypoglycemia was associated with an oligonucleosomal pattern of DNA fragmentation. Under
\end{abstract}

the same experimental conditions, the preterm ductus was capable of developing a similar degree of TUNEL-positive staining as found at term. Although caspase- 3 and caspase- 7 were activated in rings exposed to hypoxia-plus-hypoglycemia, a nonselective caspase inhibitor, Z-VAD.FMK (which inhibited caspase-3 and caspase-7 cleavage in the rings), did not diminish the degree of TUNEL-positive staining. We hypothesize that the preterm ductus is capable of developing an extensive degree of cell death, if it can develop the same degree of hypoxia and hypoglycemia found in the full-term newborn ductus. We also hypothesize that cell death in the ductus wall may involve pathways that are not dependent on caspase-3 or -7 activation. (Pediatr Res 54: 204211, 2003)

\[ \text { Abbreviations } \]
TUNEL, terminal deoxynucleotidyl transferase nick-end
labeling
PARP, poly (ADP-ribose) polymerase

In the full-term neonate, closure of the ductus arteriosus occurs in two phases: first, smooth muscle constriction reduces the size of the ductus lumen during the first hours after birth; this is followed by a second phase, involving loss of ductus responsiveness to vasoactive stimuli and anatomic remodeling of the ductus wall (1). Death of smooth muscle cells in the inner ductus muscle media plays an essential role in the loss of vasoreactivity and the anatomic remodeling $(2,3)$. Within $24 \mathrm{~h}$ of birth, more than $70 \%$ of the smooth muscle cells in the inner

Received August 2, 2002; accepted January 6, 2003

Correspondence: Ronald I. Clyman, Box 0544, HSE 1492, University of California San Francisco, 513 Parnassus Ave., San Francisco, CA 94143-0544, U.S.A.; e-mail: ric@itsa.ucsf.edu

Supported, in part, by U.S. Public Health Service National Heart, Lung, Blood Institute grants HL 46691 and HL 56061, and a gift from the Perinatal Associates Research Foundation. S.G. is a research fellow with the Stanley J. Sarnoff Endowment for Cardiovascular Research.

DOI: 10.1203/01.PDR.0000072519.61060.E5 muscle media have evidence of DNA fragmentation and cell death (demonstrated by the in situ TUNEL technique) (4).

The events that are responsible for ductus smooth muscle cell death have recently been described. During postnatal constriction, blood flowing through the vasa vasorum that penetrate and run through the outer muscle media of the ductus wall is obstructed. This produces a zone of profound hypoxia (tissue oxygen concentration $<0.4 \%$ oxygen) and nutrient ischemia in the ductus muscle media (4). Ductus constriction, and the profound ischemia that accompanies it, are required before cell death and remodeling take place $(2,5-7)$

Several of the features of smooth muscle cell death in the ductus arteriosus are consistent with an apoptotic type of programmed cell death $(2,3,5)$. Apoptosis can usually be distinguished from oncosis/necrosis by morphologic and biochemical criteria: nuclear fragmentation, chromatin condensation, presence of apoptotic bodies, and DNA fragmentation (as evidenced by agarose gel electrophoresis or by the TUNEL 
technique) (8-10). Both DNA fragmentation (detected by TUNEL technique) $(2,3)$ and the presence of pyknotic, fragmented nuclei (5) are apparent in the region of eventual cell loss in the postnatal ductus arteriosus.

Apoptosis usually involves the proteolytic activation of a family of cysteine proteases called caspases (11-13). A large body of evidence supports a cascade model for caspase activation. Proapoptotic signals are closely coupled to "initiator" caspases, which, upon activation, cleave and activate downstream "effector" caspases. Once cleaved to an active form, "effector" caspases (including caspase- 3 and caspase-7) cleave membrane, cytoskeletal, and nuclear proteins (like PARP (14, 15)), and induce apoptosis. Nonselective, irreversible inhibitors of caspase activation, like the derivatized peptide ZVAD.FMK, which inhibits cleavage of caspases-2, -3, -6, -7, and $-8(16,17)$, inhibit the induction of apoptosis $(18,19)$. Lack of response to caspase inhibitors has been used to identify caspase-independent forms of cell death (20).

In contrast with the full-term ductus, the preterm ductus frequently fails to develop a profound degree of ischemic hypoxia after birth and fails to develop an extensive region of cell death in its muscle media (2). This leads to persistent ductus vasoreactivity and persistent responsiveness to endogenous vasodilators (21). As a result, the premature ductus is susceptible to subsequent reopening, along with its associated morbidities $(2,22)$.

In the present study, we used isolated rings of fetal lamb ductus arteriosus to study the individual effects of each of the events that precede TUNEL-positive staining and cell death in the ductus wall: 1) tissue shortening and compaction, 2) hypoxia, and 3) hypoglycemia. Each of these events has been implicated in cell death in other tissue systems $(23,24)$. Because the full-term lamb ductus arteriosus develops extensive DNA fragmentation and TUNEL-positive staining in vivo ( $>70 \%$ of its cell nuclei are TUNEL-positive by $24 \mathrm{~h}$ after birth (4)), we used our in vitro model to investigate which factor(s) might be responsible for the extensive degree of TUNEL-positive staining and DNA fragmentation found in vivo. We also looked for the presence of caspase activation, both in vivo and in vitro, and examined the effects of caspase-3 and caspase-7 inhibition on TUNEL staining. Finally, we used isolated rings of preterm ductus arteriosus to determine whether the preterm ductus is capable of developing the same degree of TUNEL staining and cell death as found at term.

\section{METHODS}

All studies were approved by the Committee on Animal Research at the University of California San Francisco.

Cell death: in vivo. Late-gestation fetal lambs (mixed Western breed, $138 \pm 2 \mathrm{~d}$ gestation [term $=145 \mathrm{~d}$ gestation]), and spontaneously delivered newborn lambs were used to study caspase activation, in vivo. Fetuses were delivered by cesarean section and killed before breathing. Newborns were killed between 12 and $24 \mathrm{~h}$ after delivery with an overdose of pentobarbital sodium. At necropsy, the dilated fetal ductus and the constricted neonatal ductus were dissected in $4^{\circ} \mathrm{C}$ Dulbec- co's PBS and frozen in liquid nitrogen for subsequent Western blot analysis.

Cell death: in vitro. Late-gestation near-term lamb fetuses $(139 \pm 3 \mathrm{~d}$ gestation) and preterm lamb fetuses $(104 \pm 2 \mathrm{~d})$ were delivered by cesarean section and anesthetized with ketamine $\mathrm{HCl}(30 \mathrm{mg} / \mathrm{kg}$ i.v.) before rapid exsanguination. The ductus was divided into 1-mm-thick rings and mounted in a 20-mL organ culture bath in Krebs bicarbonate solution (5, 25, 26). The rings were stretched to lengths that produced a maximal contractile response to increases in oxygen tension (preterm $=4.0 \pm 0.1 \mathrm{~mm}$; late gestation $=6.2 \pm 0.4 \mathrm{~mm}$ ) (25). An oxygen electrode placed in the organ bath measured the oxygen concentration (5). The bath solution was equilibrated with gas mixtures containing $5 \% \mathrm{CO}_{2}$ and was exchanged at a rate of $10 \mathrm{~mL} / \mathrm{h}$. The rings were incubated for $24 \mathrm{~h}$ at different glucose concentrations $(11.1 \mathrm{mM}[2 \mathrm{mg} / \mathrm{mL}], 3.33$ $\mathrm{mM}[0.6 \mathrm{mg} / \mathrm{mL}], 1.38 \mathrm{mM}[0.25 \mathrm{mg} / \mathrm{mL}]$, and $0.56 \mathrm{mM}[0.1$ $\mathrm{mg} / \mathrm{mL}])$ and/or different oxygen concentrations $(2,6,16,30$, or $80 \%$ ). We have previously shown that a bath solution oxygen concentration of $2 \%$ produces a tissue oxygen concentration of $0.2 \%$ (5), which is the tissue concentration measured in vivo in the postnatal, full-term ductus (5). After the $24 \mathrm{~h}$ incubation, the rings were embedded in Tissue-Tek (Bayer Corporation, Elkhart, IN, U.S.A.) and frozen in liquid nitrogen (for TUNEL analysis) or frozen directly in liquid nitrogen (for Western blot and DNA analysis).

The rate of glucose utilization was estimated from the steady-state rate of lactate production during the fifth hour of incubation. The effluent from the organ bath was collected over a 1-h period and the amount of lactate in the effluent was measured with a 1506 YSI Sport lactate analyzer (YSI Inc., Yellow Springs, OH, U.S.A.). Because the rings were used for either histology or Western blot analysis, wet weights could not be obtained from the actual study rings. We used a series of parallel rings that were prepared and handled in the same way to determine the average weight of the rings. After incubation, the parallel rings were blotted dry and weighed $($ preterm $=26.4 \pm 9.4 \mathrm{mg} / \mathrm{ring}$; late gestation $=52.6 \pm 20.2$ $\mathrm{mg} / \mathrm{ring})$.

In some experiments, the effects of muscle shortening and stress relaxation on smooth muscle cell death were examined in rings from the same ductus that were mounted in separate organ baths (11.1 mM glucose, equilibrated with $80 \%$ oxygen). One ring (the "stretched ring") was stretched between two fixed hooks that were separated by $7.0 \mathrm{~mm}$ (to equal the circumference of the fetal ductus measured in vivo). To mimic the postnatal ductus shortening that occurs in vivo, the other ring (the "released ring") was hung between two hooks that were separated by $2 \mathrm{~mm}$. The released ring gradually reduced its circumference over the next $3 \mathrm{~h}$ until its maximum lumen diameter was the distance between the hooks $(2 \mathrm{~mm})$.

In some experiments, the effects of a general, irreversible, nonspecific caspase inhibitor Z-VAD.FMK (R \& D Systems, Minneapolis, MN, U.S.A.) were examined in the isolated ductus rings. The rings were initially preincubated with Krebs bicarbonate buffer (80\% oxygen, $5.5 \mathrm{mM}$ glucose) containing either $400 \mu \mathrm{M}$ Z-VAD.FMK or DMSO control. After a 4-h preincubation, the buffer was changed to $2 \%$ oxygen, $1.38 \mathrm{mM}$ 
glucose, and either $100 \mu \mathrm{M}$ Z-VAD.FMK or $0.25 \%$ DMSO control (in a total volume of $40 \mathrm{~mL}$ ), which was recirculated over the next $20 \mathrm{~h}$. The maximum concentration of $\mathrm{Z}$ VAD.FMK that could be used in our experiments was limited by the potential toxicity of the solvent DMSO. Z-VAD.FMK has been shown to inhibit apoptosis at concentrations of $<50$ $\mu \mathrm{M}$ in other tissues $(19,27)$.

Cell death. We used the TUNEL technique to detect cells in the early stages of DNA fragmentation and cell death, as we have described previously (6). DNA breaks were detected with the Apoptag peroxidase detection system (Intergen, Purchase, NY, U.S.A.). After removing the first $300 \mu \mathrm{m}$ from the 1-mmthick frozen ductus rings, we collected $6-\mu \mathrm{m}$ sections for TUNEL analysis. We have previously shown that when a ductus ring is incubated in a bath solution equilibrated with $2 \%$ oxygen, the oxygen concentration falls to $0.2 \%$ oxygen within $50-80 \mu \mathrm{m}$ of the ring's surface (5). Because there was variation in the width (distance between the lumen and adventitia) of the ductus rings, we devised a standardized technique to count the number of TUNEL-positive nuclei in the inner muscle media (Fig. 1). We identified a $180 \mu \mathrm{m}$-by-240 $\mu \mathrm{m}$ region of interest in the inner muscle media, which was located $130 \mu \mathrm{m}$ from the vessel lumen. The region of interest was located halfway between the two suspension hooks. The region was photographed and $>1000$ cells were counted in the inner muscle media on both sides of the ductus lumen.

Oligonucleosomal DNA fragmentation. Genomic DNA was isolated from rings of late gestation ductus arteriosus that had been frozen after incubation. The frozen tissue was pulverized, and genomic DNA was isolated using the NucleoSpin Tissue kit (CLONTECH, Palo Alto, CA, U.S.A.). DNA samples $(4 \mu \mathrm{g})$ from each ring were analyzed on $1 \%$ agarose gels stained with ethidium bromide and compared with a 1-kb DNA ladder (Invitrogen, Carlsbad, CA, U.S.A.).

\section{Caspase and PARP cleavage}

Ductus arteriosus tissues were lysed in lysis buffer (Tris 20 $\mathrm{mM}, \mathrm{NaCl} 137 \mathrm{mM}$, glycerol 10\%, Triton X-100 1\%, aprotinin $0.15 \mathrm{U} / \mathrm{mL}$, leupeptin $2 \mu \mathrm{M}$, Pefabloc $1 \mathrm{mM}$ (Roche)) and cleared by centrifugation for $5 \mathrm{~min}$ at $13,000 \mathrm{rpm}$. Lysate protein concentration was determined by Bradford assay. Equal amounts of lysate protein were separated by SDS-PAGE

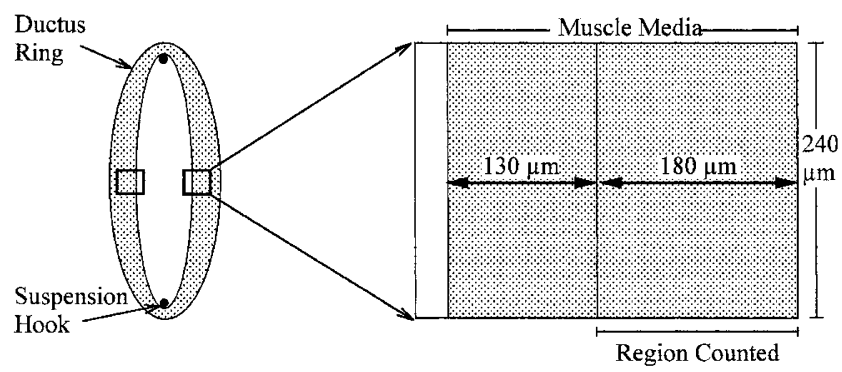

Figure 1. Illustration of region of inner muscle media used to determine the incidence of TUNEL-positive stained nuclei in the ductus ring. The 180 $\mu \mathrm{m}$-by-240 $\mu \mathrm{m}$ region was located $130 \mu \mathrm{m}$ from the luminal endothelial surface. The total distance between the luminal surface and the adventitial surface (ductus "width") was $1122 \pm 193 \mu \mathrm{m}$ in the preterm ductus and 1593 $\pm 237 \mu \mathrm{m}$ in the late-gestation ductus. and transferred to nitrocellulose. Immunoblot analysis was performed using antibodies against caspase-7, cleaved caspase-3, cleaved caspase-7, PARP (all from Cell Signaling Technology, Beverly, MA, U.S.A.). Blots were visualized by chemiluminescence (ECL; Amersham Pharmacia Biotech, Piscataway, NJ, U.S.A.).

Statistics. Statistical analysis was performed by the appropriate $t$ test and by ANOVA. Scheffé's test was used for post hoc analysis. When more than one comparison was made, Bonferroni's correction was used. Nonparametric data were compared with a Mann-Whitney test. Results are presented as means \pm SD.

\section{RESULTS}

TUNEL staining in the late gestation ductus arteriosus: in vitro. We incubated rings of late-gestation fetal lamb ductus in one of several conditions to identify which of the factors that occur in vivo are necessary for cell death (Fig. 2). When rings were incubated under control conditions (80\% oxygen and 11.1 $\mathrm{mM}$ glucose) for $24 \mathrm{~h}$ there was a low rate of TUNEL staining $(0.6 \pm 0.9 \%)$.

Incubation in a low bath oxygen concentration (2\%) significantly increased the incidence of TUNEL-positive staining 10 -fold to $6.9 \pm 3.5 \%$. However, this was far below the incidence that we observed in vivo (>70\%) (4).

The incidence of TUNEL-positive staining appeared to increase with low glucose alone $(0.56 \mathrm{mM})$, although this did not reach statistical significance (Fig. 2). However, the role for glucose deprivation became evident when the rings were made hypoxic (Figs. 2 and 3). The combination of both low oxygen and low glucose increased the incidence of TUNEL-positive staining $(83 \pm 9.5 \%)$ to the range found in vivo.

Allowing the rings to shorten during the 24-h incubation had no effect on the incidence of TUNEL staining (Fig. 4).

\section{LATE GESTATION $(n=6)$}

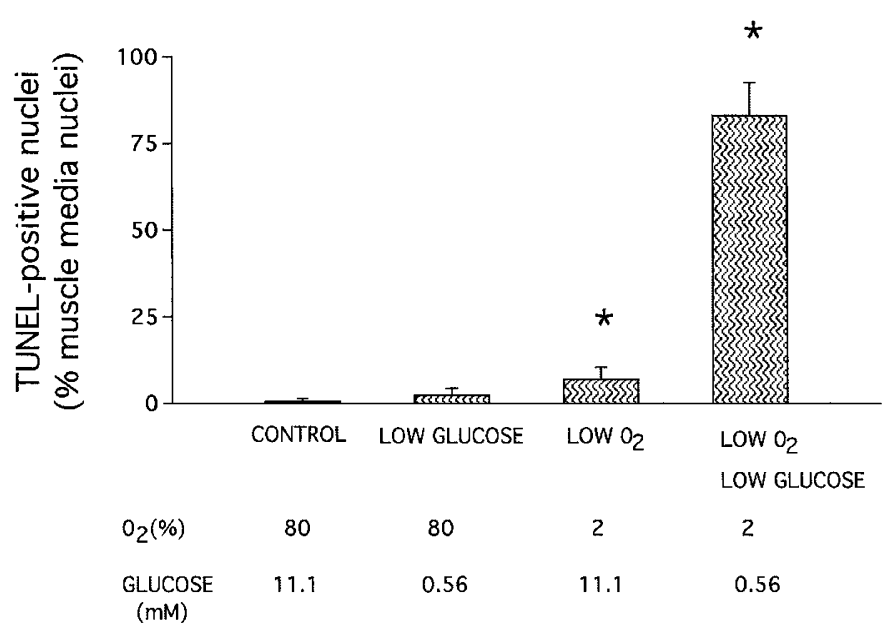

Figure 2. Effects of hypoxia and hypoglycemia on TUNEL-positive staining in rings of late-gestation fetal ductus arteriosus. Four rings per ductus were obtained from six late-gestation fetal lambs. Rings were incubated with solutions containing different oxygen and glucose concentrations for $24 \mathrm{~h}$. The inner muscle media was examined for TUNEL-positive staining. Values are mean $\pm \mathrm{SD} .{ }^{*} p<0.01$ ( $v s$ control condition). 

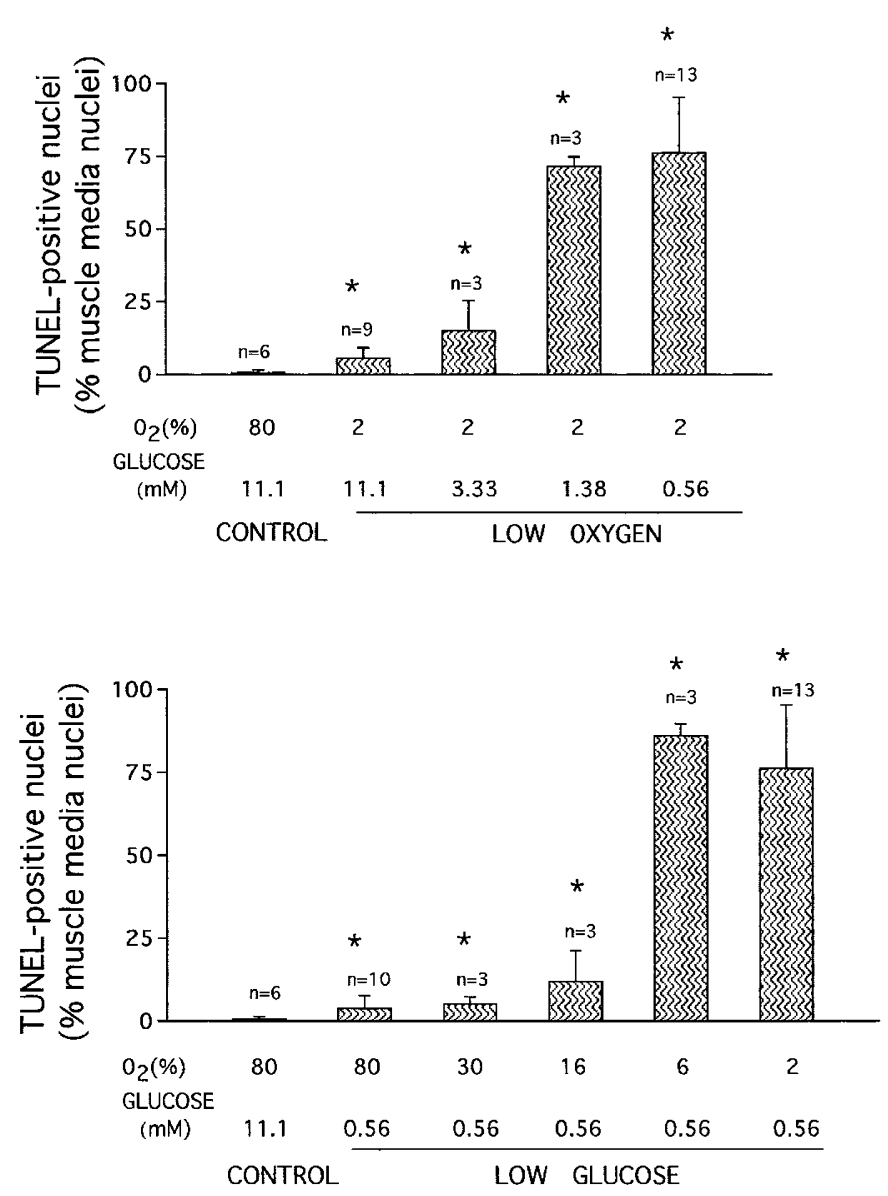

Figure 3. Effects of increasing degrees of hypoxia and hypoglycemia on TUNEL staining in rings of late-gestation fetal ductus arteriosus. Rings were incubated in solutions for $24 \mathrm{~h}$ as described in Figure 2. (Top) Rings were incubated in solutions equilibrated with low oxygen $(2 \%)$ and one of four glucose concentrations $(11.1,3.33,1.38$, or $0.56 \mathrm{mM})$. (Bottom) Rings were incubated in solutions equilibrated with low glucose $(0.56 \mathrm{mM})$ and one of five oxygen concentrations $(80,30,16,6$, and $2 \%) . n=$ number of fetuses. ${ }^{*} p<$ 0.05 vs control condition.

TUNEL-staining in the preterm ductus: in vitro. The percentages of TUNEL-positive nuclei in the preterm ductus under either control conditions $(0.75 \pm 0.75 \%)$ or under conditions of low oxygen alone $(2.4 \pm 2 \%)$ or low glucose alone $(5.0 \pm 4 \%)$ were similar to the percentages observed in late-gestation ductus (Fig. 5). Although there was a marked increase in TUNEL-positive staining in the preterm ductus in the combined low oxygen/low glucose condition, the incidence of TUNEL-positive staining in the late-gestation ductus was still significantly higher than the preterm ductus $(76 \pm 19 \%$ versus $54 \pm 20 \%, p<0.04)$. This could not be explained by differences in tissue oxygen concentration or glucose utilization rates. We have shown previously that lowering the oxygen concentration in the bath solution from $80 \%$ to $2 \%$ produces the same degree of tissue hypoxia in the preterm ductus as in the late-gestation ductus (5). Glucose utilization in the preterm ductus (as reflected by lactate production) is similar to, or tends to be greater than, the late-gestation ductus (Fig. 6).

Caspase activation: in vivo. We have shown previously that the ischemic, full-term lamb ductus arteriosus develops an

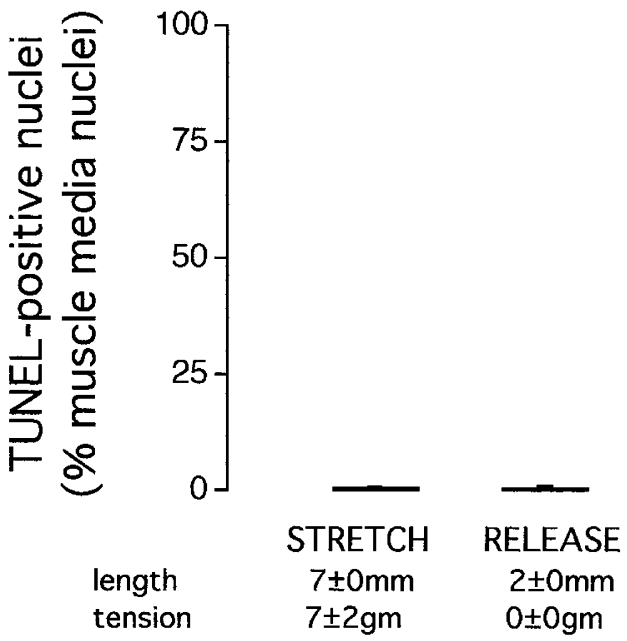

Figure 4. Effects of muscle shortening and stress-relaxation on TUNELpositive staining. Rings from the same ductus were stretched to $7 \mathrm{~mm}$ or allowed to shorten to $2 \mathrm{~mm}$. Rings were incubated in control solution (80\% oxygen, $11 \mathrm{mM}$ glucose; see Fig. 2) for $24 \mathrm{~h}$. Isometric tension in the rings was measured as previously described (25). $n=$ four late-gestation fetuses.

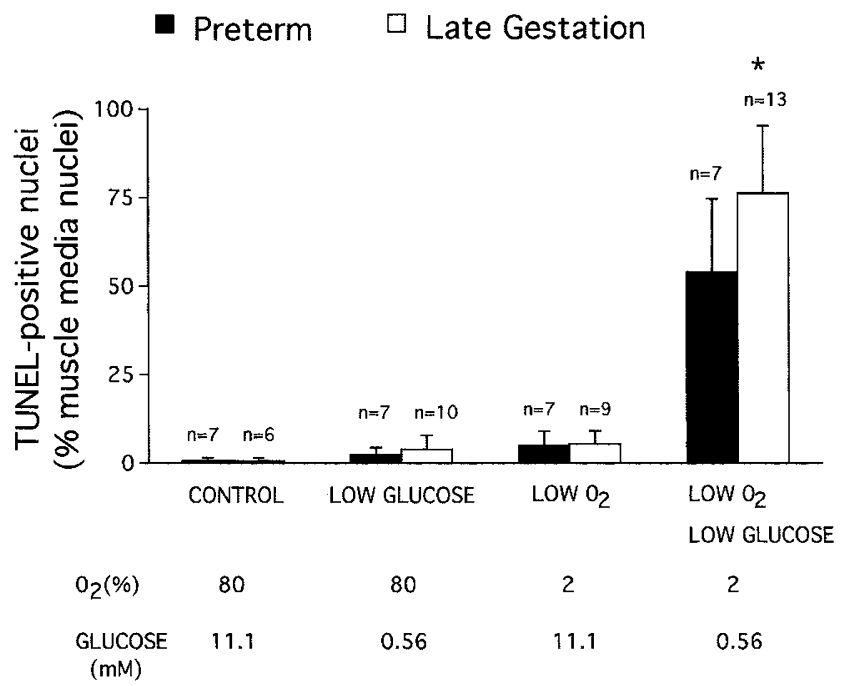

Figure 5. Effects of hypoxia and hypoglycemia on TUNEL-positive staining in preterm and late gestation ductus. Rings were incubated in solutions for $24 \mathrm{~h}$ as described in Figure 2. $n=$ number of fetuses. ${ }^{*} p<0.05$ late gestation $v s$ preterm.

extensive zone of DNA fragmentation and TUNEL staining by $24 \mathrm{~h}$ after birth (4). Therefore, we looked for evidence of caspase- 3 activation in the ductus from late-gestation fetuses and from spontaneously delivered full-term lambs. Activation of caspase-3 requires proteolytic processing of its inactive zymogen into an active $17-\mathrm{kD}$ subunit. The $17-\mathrm{kD}$ cleaved fragment of caspase- 3 was apparent in each of the newborn ductus but in none of the fetal ductus (Fig. 7). Similarly, PARP, which is cleaved by activated "effector" caspases, was reduced in the newborn ductus compared with the fetal ductus (Fig. 7).

Caspase activation: in vitro. We examined isolated rings of ductus arteriosus under conditions of low oxygen/low glucose to determine whether the marked increase in TUNEL-positive staining could be attributed to a caspase-3 and/or caspase-7mediated apoptosis. DNA extracted from rings maintained 


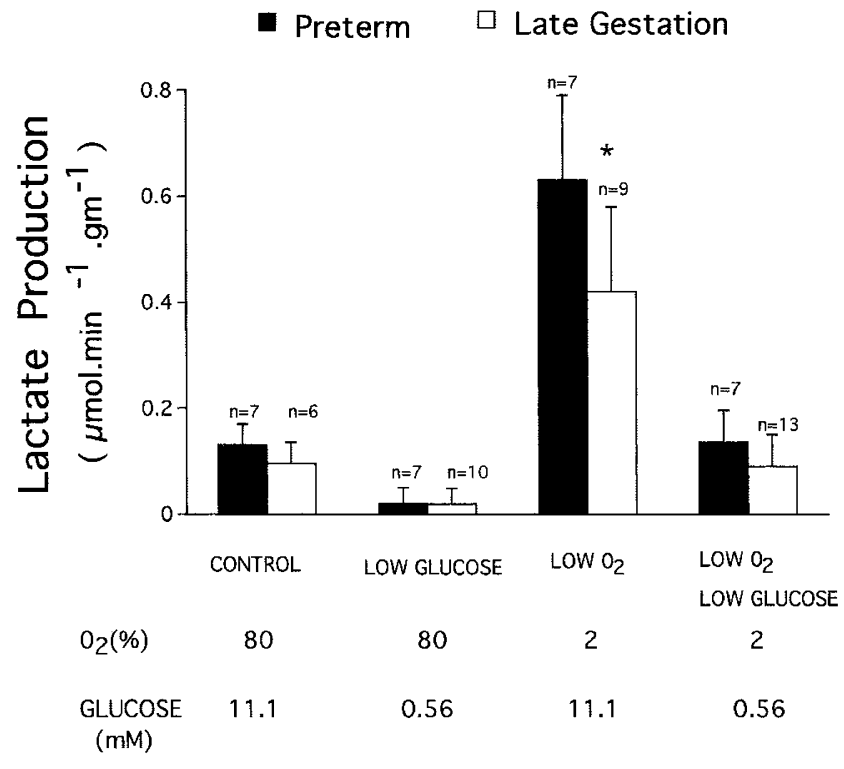

Figure 6. Steady state rate of lactate production by rings of preterm and late-gestation ductus. Rings used in Figure 5 were perfused with bath solution at a rate of $10 \mathrm{~mL} / \mathrm{h}$. The effluent was collected over a 1-h period, during the fifth hour of incubation. $n=$ number of fetuses. ${ }^{*} p<0.05$ late-gestation $v s$ preterm.

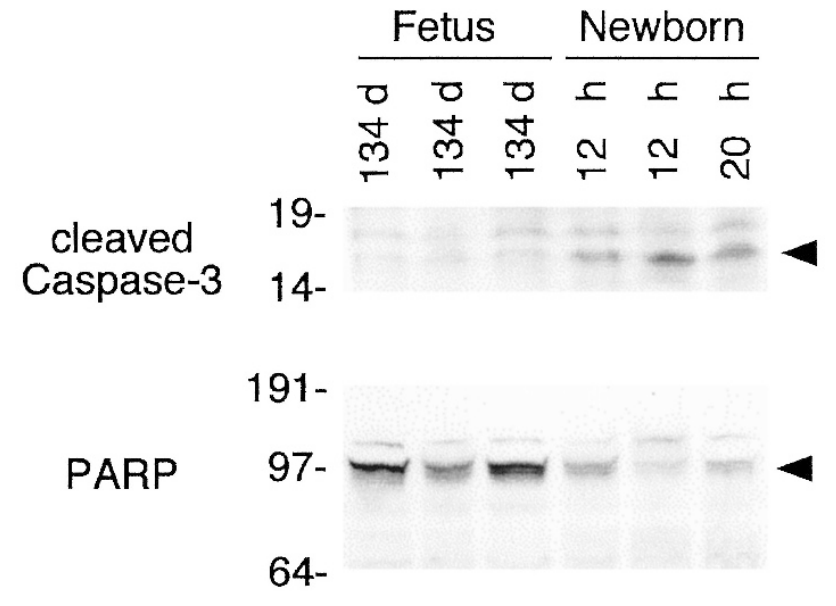

Figure 7. Caspase- 3 cleavage and PARP reduction in the newborn ductus arteriosus. Thirty micrograms of protein lysates from three fetal and three newborn ductus were examined by Western blot analysis for the presence of the $17-\mathrm{kD}$ cleaved fragment of caspase- 3 and the uncleaved, intact form of PARP (100 kD). Caspase-3 cleavage fragments were present in all of the newborn but none of the fetal ductus. Similarly, the amount of uncleaved PARP was reduced in the newborn ductus compared with the fetal ductus. No PARP cleavage fragments $(89 \mathrm{kD})$ were apparent in either the fetal or neonatal ductus. Similar results were obtained in experiments with four additional fetal and three additional neonatal ductus (data not shown).

under control conditions for $24 \mathrm{~h}$ remained intact without significant fragmentation (Fig. 8). However, exposure to low oxygen/low glucose induced a pattern of oligonucleosomal DNA fragmentation indicative of apoptotic cell death. This pattern was visible with as little as $8 \mathrm{~h}$ of exposure to low oxygen/low glucose" (data not shown).

Before the incubation in low oxygen/low glucose, rings of ductus arteriosus had no evidence of caspase-3, caspase-7, or PARP cleavage (as demonstrated by the absence of their

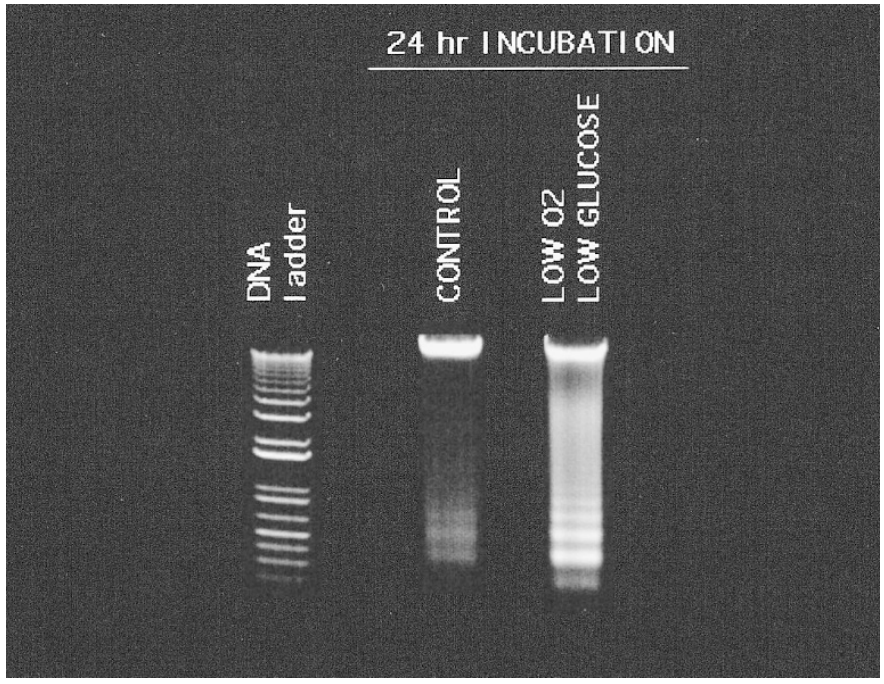

Figure 8. Low oxygen and low glucose induce oligonucleosomal DNA fragmentation. Rings of the same ductus were incubated for $24 \mathrm{~h}$ in control solution ( $80 \%$ oxygen, $11.1 \mathrm{mM}$ glucose) or solution containing low oxygen/ low glucose ( $2 \%$ oxygen, $0.56 \mathrm{mM}$ glucose). The lanes represent a DNA standard ladder, and genomic DNA ( $4 \mu \mathrm{g})$ from each ring. This experiment was repeated three times with similar results (data not shown).

respective cleavage fragments (Fig. $9 A$, see " 0 h"). By 3 h of exposure to low oxygen/low glucose, cleavage fragments of caspase-3 (17 kD), caspase-7 (20 kD), and PARP (89 kD) began to appear in the ductus rings. The cleavage fragments increased in abundance by $8 \mathrm{~h}$, and were already waning in appearance by $24 \mathrm{~h}$ of exposure to low oxygen/low glucose (Fig. 9A). By $24 \mathrm{~h}$, a marked reduction in the amounts of the uncleaved forms of caspase-7 and PARP was apparent in the low oxygen/low glucose exposed rings (Fig. 9B). In contrast, rings of ductus arteriosus that were incubated in control conditions for $24 \mathrm{~h}$ had no reduction in the amount of intact caspase-7 and PARP (Fig. 9B).

Incubating the rings with the nonselective, general caspase inhibitor Z-VAD.FMK before and during the exposure to low oxygen/low glucose inhibited the cleavage of caspase-3, caspase-7, and PARP. Z-VAD.FMK both decreased the abundance of cleavage fragments of caspase-3, caspase-7, and PARP and prevented the loss of intact PARP when compared with tissues that were not incubated with Z-VAD.FMK (Fig. $9 A)$.

Although Z-VAD.FMK inhibited caspase cleavage during the low oxygen/low glucose condition, it did not diminish the amount of DNA fragmentation and TUNEL staining in this condition (Fig. 10).

\section{DISCUSSION}

In addition to the presence of DNA fragmentation and the appearance of pyknotic and fragmented nuclei $(2,3,7)$ in the postnatal newborn ductus, we found evidence of caspase-3 activation in vivo (Fig. 7). By $24 \mathrm{~h}$ after birth, both cleavage of caspase- 3 and reduction in the amount of uncleaved PARP were apparent in the newborn ductus. We were unable to detect PARP cleavage products in the newborn ductus. This may be 


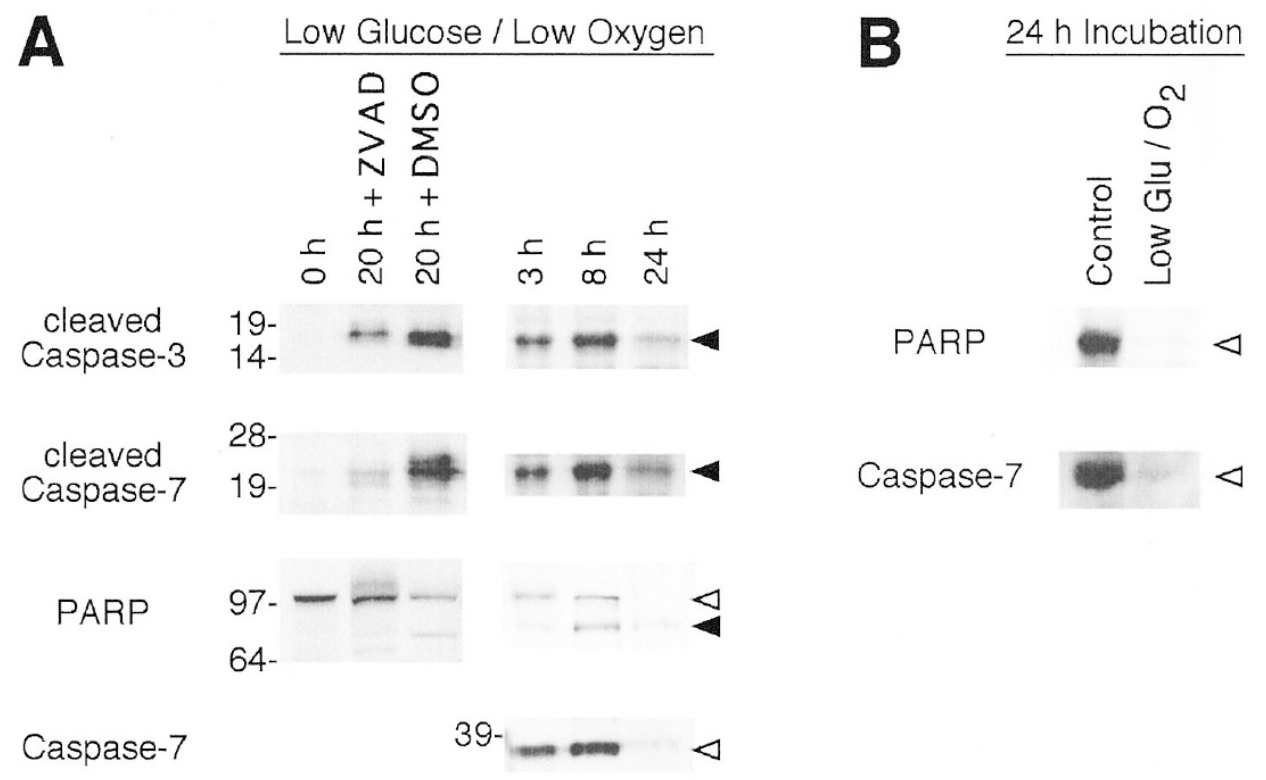

Figure 9. Caspase-3, caspase-7, and PARP fragmentation is induced by low oxygen and low glucose and inhibited by Z-VAD.FMK. (A) Rings from the same late gestation ductus were either a) frozen directly after dissection $(0 \mathrm{~h})$ or b) incubated for $20 \mathrm{~h}$ in low oxygen and low glucose ( $2 \%$ oxygen, $1.38 \mathrm{mM}$ glucose) after pretreatment with Z-VAD.FMK or its solvent DMSO, see "Methods," or c) incubated for 3, 8, or $24 \mathrm{~h}$ in low oxygen and low glucose (2\% oxygen, 0.56 $\mathrm{mM}$ glucose). (B) Rings from the same late gestation ductus were incubated in control (80\% oxygen, $11.1 \mathrm{mM}$ glucose) or in low oxygen and low glucose ( $2 \%$ oxygen, $0.56 \mathrm{mM}$ glucose) conditions for $24 \mathrm{~h}$. Protein lysates $(30 \mu \mathrm{g})$ from the rings were examined for the presence of cleavage products (dark arrowheads) of caspase-3, caspase-7, and PARP and for the intact, uncleaved forms of caspase-3, caspase-7, and PARP (open arrowheads). Ductus from five fetuses were used in these experiments. The immunoblots comparing the protein lysates from rings frozen at $0 \mathrm{~h}$ with those frozen after $20 \mathrm{~h}$ of incubation with either Z-VAD.FMK or DMSO were overexposed to maximize the detection of the cleavage products of caspase-3, caspase-7, and PARP. Note: DMSO had no effect on the pattern of cleaved and uncleaved forms of caspase-3, caspase-7, and PARP in rings that were incubated for $24 \mathrm{~h}$ in either control conditions ( $80 \%$ oxygen, $11.1 \mathrm{mM}$ glucose) or low oxygen/low glucose conditions ( $2 \%$ oxygen, $1.38 \mathrm{mM}$ glucose) (data not shown).

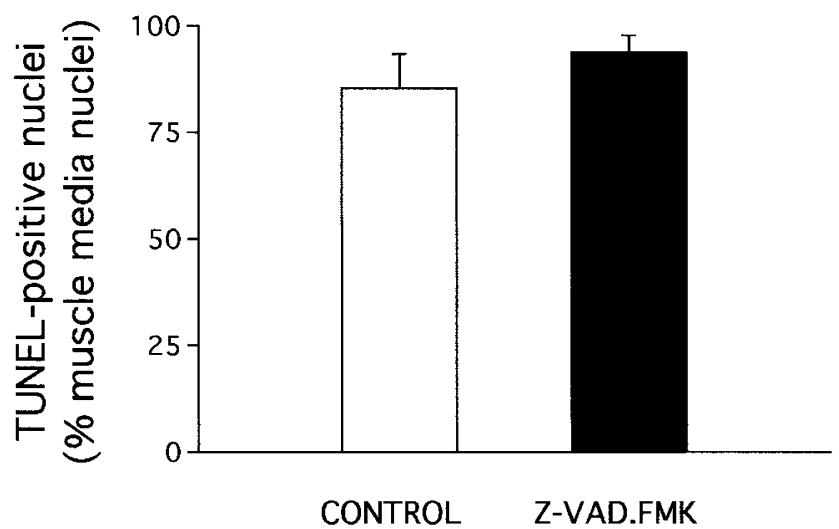

Figure 10. Z-VAD.FMK does not reduce TUNEL-positive staining in ductus rings incubated in low oxygen and low glucose. Rings from the same late gestation ductus were incubated for $20 \mathrm{~h}$ in $2 \%$ oxygen and $1.38 \mathrm{mM}$ glucose after pretreatment with Z-VAD.FMK or DMSO (control) (see "Methods" and Fig. $9 A) . n=$ three late-gestation fetuses.

the result of the rapid turnover of PARP fragments in ductus cells (Fig. 9A).

Although postnatal ductus constriction and muscle media hypoxia are associated with cell death in vivo, our studies showed that neither condition is sufficient in vitro to produce the extensive degree of cell death that is observed in vivo. Circumferential shortening of the ductus to $<30 \%$ of its original diameter has no effect on the incidence of cell death (Fig. 4). Severe hypoxia by itself does produce a significant increase in cell death; however, the rate of TUNEL-positive staining with hypoxia alone $(7 \pm 3 \%)$ is far below the rate that is observed in vivo (>70\%) (4). Only the simultaneous deprivation of both oxygen and glucose produces the extensive degree of cell death observed in vivo (Figs. 2 and 3). Exposure of the fetal ductus, in vitro, to the low oxygen/low glucose combination produces a pattern of TUNEL staining, caspase activation, and oligonucleosomal DNA fragmentation (Figs. 2, 8, and 9) that is similar to the pattern observed in vivo in the newborn ductus (Fig. 7) (4).

In the late gestation ductus, constriction compresses the intramural vasa vasorum, thereby eliminating oxygen and glucose delivery to the muscle media (4). In contrast with the late gestation ductus, the preterm ductus does not depend on vasa vasorum to nourish its wall. The preterm ductus receives all of its nutrient supply from its luminal blood flow (4). As a result, the preterm ductus must obliterate its luminal flow completely before it can develop the same degree of ischemic hypoxia as found at term. Our in vitro studies show that the preterm ductus is capable of developing an extensive degree of TUNELpositive staining $(54 \%)$ when it develops severe hypoxia and hypoglycemia (Fig. 5). This is consistent with recent in vivo observations of DNA fragmentation and cell death in preterm ductus that have undergone complete luminal obliteration during postnatal constriction $(5,7)$. Despite the presence of extensive cell death in the preterm ductus under conditions of low oxygen/low glucose, the incidence is significantly lower than that found in the late-gestation ductus (Fig. 5). This cannot be explained by developmental differences in tissue oxygen con- 
centrations or glucose utilization rates (Fig. 6). Alternative explanations may include developmental differences in the mechanisms used to normalize intracellular $\mathrm{pH}$ during the ischemic challenge (e.g. developmental changes in the $\mathrm{Na}^{+} / \mathrm{H}^{+}$or $\mathrm{Na}^{+} / \mathrm{Ca}^{++}$exchangers, or in the $\mathrm{Na}^{+}$-dependent $\mathrm{HCO}_{3}{ }^{-} / \mathrm{Cl}^{-}$ antiporter). These possibilities deserve further analysis in the future. Although not tested in our experiments, the lower rate of cell death in the preterm ductus might make the premature ductus more resistant to tissue remodeling at milder degrees of tissue hypoxia and hypoglycemia. The current in vitro studies, in addition to the two in vivo studies cited above $(5,7)$, underscore the critical importance of initial ductus constriction in triggering the subsequent steps that lead to permanent ductus closure in the preterm infant. They demonstrate that, although the preterm infant must develop a tighter degree of ductus constriction than the full-term infant to produce a similar degree of ischemic hypoxia, once this develops the preterm ductus is fully capable of undergoing anatomic remodeling.

The extensive degree of TUNEL-positive staining after incubation of the isolated rings in low oxygen/low glucose is associated with a marked degree of oligonucleosomal DNA fragmentation (Fig. 8). This is preceded by evidence of caspase-3 and caspase-7 activation (Fig. 9). These changes are similar to those observed in vivo in the ischemic zone of the newborn ductus (Fig. 7) (see Ref. (4)). Although caspase-3 and caspase-7 appear to be activated during hypoxia and hypoglycemia, they may not play an essential role in producing TUNEL-positive staining and cell death. In our experiments, Z-VAD.FMK, the cell-permeable irreversible caspase inhibitor, inhibited caspase- 3 and caspase- 7 cleavage in the ductus under conditions of low oxygen/low glucose (Fig. 9); however, Z-VAD.FMK did not alter the marked increase in TUNELpositive staining in this condition (Fig. 10). Because the maximal concentrations of Z-VAD.FMK used in our experiments did not completely eliminate caspase- 3 and caspase- 7 cleavage, we hypothesize that either very little caspase-3 or caspase-7 activation is necessary to produce DNA fragmentation in the wall of the ductus, or that TUNEL-positive staining and cell death in the ductus may involve additional pathways that are not dependent on caspase-3 or caspase-7 activation $(28,29)$. Recently, caspase- 9 has been shown to direct some nonapoptotic forms of programmed cell death (30). However, in preliminary experiments, we found no evidence of caspase-9 processing in the hypoxic and hypoglycemic ductus (data not shown). Other possible mechanisms that could play a role in this process might involve the mitochondrial apoptosisinducing factor (AIF) (31), proteins that regulate endogenous caspase inhibitors $(32,33)$, or other noncaspase proteases like calpains or cathepsins $(34,35)$. Whether these or other forms of caspase-independent programmed cell death (36) are crucial for ductus remodeling must await further investigation.

\section{REFERENCES}

1. Clyman RI, Mauray F, Roman C, Heymann MA, Payne B 1983 Factors determining the loss of ductus arteriosus responsiveness to prostaglandin $\mathrm{E}_{2}$. Circulation 68:433436

2. Clyman RI, Chan CY, Mauray F, Chen YQ, Cox W, Seidner SR, Lord EM, Weiss H, Wale N, Evan SM, Koch CJ 1999 Permanent anatomic closure of the ductus arteriosus in newborn baboons: the roles of postnatal constriction, hypoxia, and gestation. Pediatr Res 45:19-29

3. Slomp J, Gittenberger-de Groot AC, Glukhova MA, Conny van Munsteren J, Kockx MM, Schwartz SM, Koteliansky VE 1997 Differentiation, dedifferentiation, and apoptosis of smooth muscle cells during the development of the human ductus arteriosus. Arterioscler Thromb Vasc Biol 17:1003-1009

4. Kajino H, Goldbarg S, Roman C, Liu BM, Mauray F, Chen YQ, Takahashi Y, Koch CJ, Clyman RI 2002 Vasa vasorum hypoperfusion is responsible for medial hypoxia and anatomic remodeling in the newborn lamb ductus arteriosus. Pediatr Res 51:228235

5. Kajino H, Chen YQ, Seidner SR, Waleh N, Mauray F, Roman C, Chemtob S, Koch CJ, Clyman RI 2001 Factors that increase the contractile tone of the ductus arteriosus also regulate its anatomic remodeling. Am J Physiol 281:R291-R301

6. Goldbarg SH, Takahashi Y, Cruz C, Kajino H, Roman C, Liu BM, Chen YQ, Mauray $\mathrm{F}$, Clyman RI 2002 In utero indomethacin alters $\mathrm{O}_{2}$ delivery to the fetal ductus arteriosus: implications for postnatal patency. Am J Physiol Regul Integr Comp Physiol 282:R184-R190

7. Seidner SR, Chen Y-Q, Oprysko PR, Mauray F, Tse MM, Lin E, Koch C, Clyman RI 2001 Combined prostaglandin and nitric oxide inhibition produces anatomic remodeling and closure of the ductus arteriosus in the premature newborn baboon. Pediatr Res 50:365-373

8. Majno G, Joris I 1995 Apoptosis, oncosis, and necrosis. An overview of cell death Am J Pathol 146:3-15

9. Gavrieli Y, Sherman Y, Ben-Sasson SA 1992 Identification of programmed cell death in situ via specific labeling of nuclear DNA fragmentation. J Cell Biol 119:493-501

10. Oberhammer F, Wilson JW, Dive C, Morris ID, Hickman JA, Wakeling AE, Walker PR, Sikorska M 1993 Apoptotic death in epithelial cells: cleavage of DNA to 300 and/or $50 \mathrm{~kb}$ fragments prior to or in the absence of internucleosomal fragmentation. EMBO J 12:3679-3684

11. Cohen GM 1997 Caspases: the executioners of apoptosis. Biochem J 326:1-16

12. Nunez G, Benedict MA, Hu Y, Inohara N 1998 Caspases: the proteases of the apoptotic pathway. Oncogene 17:3237-3245

13. Salvesen GS, Dixit VM 1997 Caspases: intracellular signaling by proteolysis. Cell 91:443-446

14. Lazebnik YA, Kaufmann SH, Desnoyers S, Poirier GG, Earnshaw WC 1994 Cleavage of poly(ADP-ribose) polymerase by a proteinase with properties like ICE. Nature 371:346-347

15. Nicholson DW, Ali A, Thornberry NA, Vaillancourt JP, Ding CK, Gallant M, Gareau Y, Griffin PR, Labelle M, Lazebnik YA, Munday NA, Raju SM, Smulson ME, Yamin T-T, Yu VL, Miller DK 1995 Identification and inhibition of the ICE/CED-3 protease necessary for mammalian apoptosis. Nature 376:37-43

16. Muzio M, Chinnaiyan AM, Kischkel FC, O’Rourke K, Shevchenko A, Ni J, Scaffidi C, Bretz JD, Zhang M, Gentz R, Mann M, Krammer PH, Peter ME, Dixit VM 1996 FLICE, a novel FADD-homologous ICE/CED-3-like protease, is recruited to the CD95 (Fas/APO-1) death-inducing signaling complex. Cell 85:817-827

17. MacFarlane M, Cain K, Sun XM, Alnemri ES, Cohen GM 1997 Processing/activation of at least four interleukin-1beta converting enzyme-like proteases occurs during the execution phase of apoptosis in human monocytic tumor cells. J Cell Biol 137:469479

18. Gastman BR, Johnson DE, Whiteside TL, Rabinowich H 1999 Caspase-mediated degradation of T-cell receptor zeta-chain. Cancer Res 59:1422-1427

19. Zaks TZ, Chappell DB, Rosenberg SA, Restifo NP 1999 Fas-mediated suicide of tumor-reactive $\mathrm{T}$ cells following activation by specific tumor: selective rescue by caspase inhibition. J Immunol 162:3273-3279

20. Kitanaka C, Kuchino Y 1999 Caspase-independent programmed cell death with necrotic morphology. Cell Death Differ 6:508-515

21. Clyman RI, Campbell D, Heymann MA, Mauray F 1985 Persistent responsiveness of the neonatal ductus arteriosus in immature lambs: a possible cause for reopening of patent ductus arteriosus after indomethacin induced closure. Circulation 71:141-145

22. Narayanan M, Cooper B, Weiss H, Clyman RI 2000 Prophylactic indomethacin factors determining permanent ductus arteriosus closure. J Pediatr 136:330-337

23. Grinnell F, Zhu M, Carlson MA, Abrams JM 1999 Release of mechanical tension triggers apoptosis of human fibroblasts in a model of regressing granulation tissue. Exp Cell Res 248:608-619

24. Bhattacharjee R, Cowan KN, Leung WCY, Rabinovitch M 2001 Stress unloading induction of apoptosis and apoptosis mediated matrix degradation contributes to regression of pulmonary artery hypertrophy. Pediatr Res 49:305A(abstr)

25. Clyman RI, Mauray F, Wong L, Heymann MA, Rudolph AM 1978 The developmental response of the ductus arteriosus to oxygen. Biol Neonate 34:177-181

26. Kajino H, Chen YQ, Chemtob S, Waleh N, Koch CJ, Clyman RI 2000 Tissue hypoxia inhibits prostaglandin and nitric oxide production and prevents ductus arteriosus reopening. Am J Physiol 279:R278-R286

27. Guo Y, Kyprianou N 1999 Restoration of transforming growth factor beta signaling pathway in human prostate cancer cells suppresses tumorigenicity via induction of caspase-1-mediated apoptosis. Cancer Res 59:1366-1371

28. Sarin A, Wu ML, Henkart PA 1996 Different interleukin-1 beta converting enzyme (ICE) family protease requirements for the apoptotic death of T lymphocytes triggered by diverse stimuli. J Exp Med 184:2445-2450

29. Xiang J, Chao DT, Korsmeyer SJ 1996 BAX-induced cell death may not require interleukin 1 beta-converting enzyme-like proteases. Proc Natl Acad Sci U S A 93:14559-14563

30. Sperandio S, de Belle I, Bredesen DE 2000 An alternative, nonapoptotic form of programmed cell death. Proc Natl Acad Sci U S A 97:14376-14381

31. Joza N, Susin SA, Daugas E, Stanford WL, Cho SK, Li CY, Sasaki T, Elia AJ, Cheng HY, Ravagnan L, Ferri KF, Zamzami N, Wakeham A, Hakem R, Yoshida H, Kong YY, 
Mak TW, Zuniga-Pflucker JC, Kroemer G, Penninger JM 2001 Essential role of the mitochondrial apoptosis-inducing factor in programmed cell death. Nature 410:549-554

32. Verhagen AM, Ekert PG, Pakusch M, Silke J, Connolly LM, Reid GE, Moritz RL, Simpson RJ, Vaux DL 2000 Identification of DIABLO, a mammalian protein that promotes apoptosis by binding to and antagonizing IAP proteins. Cell 102:43-53

33. Silke J, Hawkins CJ, Ekert PG, Chew J, Day CL, Pakusch M, Verhagen AM, Vaux DL 2002 The anti-apoptotic activity of XIAP is retained upon mutation of both the caspase 3- and caspase 9-interacting sites. J Cell Biol 157:115-124
34. Wang KK 2000 Calpain and caspase: can you tell the difference? Trends Neurosci 23:20-26

35. Johnson DE 2000 Noncaspase proteases in apoptosis. Leukemia 14:1695-1703

36. Kitanaka C, Kato K, Ijiri R, Sakurada K, Tomiyama A, Noguchi K, Nagashima Y, Nakagawara A, Momoi T, Toyoda Y, Kigasawa H, Nishi T, Shirouzu M, Yokoyama S, Tanaka Y, Kuchino Y 2002 Increased Ras expression and caspase-independent neuroblastoma cell death: possible mechanism of spontaneous neuroblastoma regression. J Natl Cancer Inst 94:358-368 